\title{
The Correlation of Environmental Temperature with Feed and Water Intake of Friesian Holstein Cattle in Dry Land
}

\author{
Theresia Ika Purwantiningsih ${ }^{1 *}$, Remigius Binsasi ${ }^{2}$, and Damasus C. Da Cruz ${ }^{1}$ \\ ${ }^{I}$ Department of Animal Science, Faculty of Agriculture, Universitas Timor, Kefamenanu, 85616 \\ ${ }^{2}$ Department of Biology, Faculty of Agriculture, Universitas Timor, Kefamenanu, 85616 \\ *Corresponding author. Email: theresiaicha@gmail.com
}

\begin{abstract}
This research aims to determine the correlation of environmental temperature with feed and water intake of Friesian Holstein (FH) Cattle in the dry land. This study used three FH Cattle aged 5 to 8 years and was conducted at SKKP Suluh Obor Dairy Farm, Mandeu, Raimanuk, Belu, East Nusa Tenggara, Indonesia for 30 days. The data were analyzed using Pearson Correlation. The results of this study showed the correlation value between environmental temperature with feed and water intake was 0.224 and 0.400, respectively. Environmental temperature correlated with feed and water intake.
\end{abstract}

Keywords: Environmental temperature, Feed Intake, Water Intake, Dairy Cows, Dry Land

\section{INTRODUCTION}

The breed of dairy cows almost farmed in Indonesia was the Friesian Holstein. The milk production of these cows in Indonesia was not maximized compared with their origin place. This is influenced by several factors including climate, feed, and genetic quality. The most dominant factor influencing milk production was environmental conditions. The environment directly affects the physiology of livestock, which is closely related to productivity. The response of livestock affects the metabolic rate in the process of biosynthesis of milk so that the composition and quality of milk changes. Friesian Holstein cattle in Indonesia had an average milk production of about 10 liters per day with calving intervals of 12-15 months and lactation duration of approximately 10 months or milk production on average, 2500-3000 liters per lactation [1].

East Nusa Tenggara was known as a province with dry land and water restrictions. It was influencing the number of dairy cows kept in this area. SKKP Suluh Obor farmed dairy cows in Timor Island. Environmental stress will decrease dairy cow productivity. The impact of it caused a decrease in dry matter consumption and water intake. In extreme conditions, dairy cows tend to reduce dry matter consumption, even stop consuming feed [2].
Temperature affects the productivity of dairy cows, especially breeds from sub-tropical regions such as FH cattle. Consumption of feed and water was an influence on the milk production by dairy cattle. Based on that statement, the purpose of this study was to find a correlation between environmental temperature with feed and water intake of $\mathrm{FH}$ cattle in dry land areas.

\section{MATERIAL AND METHODS}

\subsection{Material}

Three head of 5-8 years old Friesian Holstein lactating dairy cows were used in this research. Environmental temperature measured with a thermohygrometer.

\subsection{Methods}

The study was conducted in SKKP Suluh Obor Dairy Farm, Mandeu, Raimanuk, Belu, East Nusa Tenggara, Indonesia for 30 days. Feeding and watering was done once a day at 08.00. The environmental temperature, feed and water intake were observed. Environmental temperature was recorded every 2 hours from 08.00 untill 16.00 every day. The data were analyzed using Pearson Correlation. 


\section{RESULTS AND DISCUSSION}

\subsection{Correlation Between Environmental Temperature and Feed Intake}

The ideal environmental temperature to reach optimal milk production is $15.5^{\circ} \mathrm{C}$. The critical temperature for Friesian Holstein $(\mathrm{FH})$ dairy cows is $27^{\circ} \mathrm{C}$ [3]. Indonesia is a tropical country with a relatively high environmental temperature. During the day, the environmental temperature reaches $34^{\circ} \mathrm{C}$ and results in heat stress on livestock. Temperature and humidity that exceed the critical level will cause dairy cows to be exposed to heat stress [4]. A comfortable temperature and humidity for $\mathrm{FH}$ cows are $13-25^{\circ} \mathrm{C}$ and 50-60\%, respectively [5]. Dairy cows were raised in lowland areas with high temperature and humidity tend to be reduced feed intake. The critical temperature environment and heat stress on dairy farms are some of the problems that cause economic losses due to decreased livestock productivity. Table 1 shows the correlation between environmental temperature and dairy cows' feed intake.

Table 1. Correlation analysis between environmental temperature and feed intake of Frisian Holstein Cattle in dry land

\begin{tabular}{|c|c|c|c|}
\hline \multicolumn{4}{|c|}{ Correlations } \\
\hline & & Temperature & $\begin{array}{l}\text { Feed } \\
\text { Intake }\end{array}$ \\
\hline \multirow[t]{2}{*}{ Temperature } & $\begin{array}{l}\text { Pearson } \\
\text { correlation }\end{array}$ & 1 & 0.224 \\
\hline & $\begin{array}{l}\text { Sig. (2- } \\
\text { tailed) }\end{array}$ & & 0.217 \\
\hline \multirow[t]{2}{*}{ Feed Intake } & $\begin{array}{l}\text { Pearson } \\
\text { correlation }\end{array}$ & 0.224 & 1 \\
\hline & $\begin{array}{l}\text { Sig. (2- } \\
\text { tailed) }\end{array}$ & 0.217 & \\
\hline
\end{tabular}

The result shows that the correlation between temperature and feed intake is too weak (0.224). When the environmental conditions were high, the feed intake will decrease. Otherwise, the water intake will increase. This relates to livestock's effort to manage temperature balance between body and environment. High environmental temperature is adverse for livestock because it will affect feed intake, water intake, and behavior. Cows in highenvironmental temperatures will stress and fail to regulate body heat. As a result, cows will drink a lot of water but eat less and reduce feed intake. Several studies reported that environmental temperature affects feed intake. This result was in line with [6] which states that one of the factors that affect feed intake is environmental temperature.

\subsection{Correlation Between Environmental Temperature and Water Intake}

Environmental factors that were very influential on dairy cows, especially during lactation (milk production), were temperature, which was always closely related to humidity. Dairy cows must be kept in comfortable environmental conditions to produce well [7]. The provision of drinking water was important for milk production because $87 \%$ of milk consists of water and $50 \%$ of the cow's body consists of water. The amount of water needed depends on; a) the production of milk produced by a cow; $b$ ). ambient temperature, c) the feed provided [8]. The results of the correlation analysis between environmental temperature and drinking water intake of $\mathrm{FH}$ Cattle could be seen in Table 2 .

Table 2. Results of correlation analysis between environmental temperature and water intake of Frisian Holstein Cattle in dry land

\begin{tabular}{|c|c|c|c|}
\hline \multicolumn{4}{|c|}{ Correlations } \\
\hline & & Temperature & $\begin{array}{c}\text { Drink } \\
\text { Consumption }\end{array}$ \\
\hline \multirow[t]{2}{*}{ Temperature } & $\begin{array}{l}\text { Pearson } \\
\text { correlation }\end{array}$ & 1 & 0.400 \\
\hline & $\begin{array}{l}\text { Sig. (2- } \\
\text { tailed) }\end{array}$ & & 0.023 \\
\hline \multirow[t]{2}{*}{$\begin{array}{l}\text { Drink } \\
\text { Consumption }\end{array}$} & $\begin{array}{l}\text { Pearson } \\
\text { correlation }\end{array}$ & 0.400 & 1 \\
\hline & $\begin{array}{l}\text { Sig. (2- } \\
\text { tailed) }\end{array}$ & 0.023 & \\
\hline
\end{tabular}

The results of this study indicate that the correlation value was 0.400 , this means that there was a strong correlation and there was an influence between the temperature on water intake. Temperature and humidity were two climatic factors that affect the balancing of body heat, water, and energy of livestock. The high environmental temperature will affect animal body temperature, which caused heat stress, furthermore, it will decrease feed and water intake. Management had to provide adequate water intake was needed to increase milk production. When it was high-temperature conditions, animal growth and productivity will decline. Consuming water became a way for livestock to maintain body temperature.

The Environmental was a factor that had a large enough influence on the level of production. Dairy cows must be kept in comfortable environmental conditions to produce well. This was supported by Mukhtar [9] who states that at an environmental temperature of around $18.30^{\circ} \mathrm{C}-21.10^{\circ} \mathrm{C}$, dairy cattle can maintain their milk production and decrease when the temperature exceeds $26.6^{\circ} \mathrm{C}$. Rumentor [10] states that milk production will decrease if cattle experience heat stress, the effect of heat stress on milk production 
was due to increased maintenance requirements to remove heat moisture, reduce metabolic rate and reduce consumption.

\section{CONCLUSION}

The conclusion of this study was environmental temperature was correlated with feed and water intake of FH Cattle in dry land.

\section{ACKNOWLEDGMENT}

This work supported by Ministry of Research and Technology under the project of Penelitian Dosen Pemula 2021.

\section{REFERENCES}

[1] Prihadi, S. 1997. Dasar Ilmu Ternak Perah. Fakultas Peternakan Universitas Gadjah Mada, Yogyakarta.

[2] Palulungan, J.A., Adiarto dan T. Hartatik. 2013. Pengaruh Kombinasi Pengkabutan dan Kipas Angin terhadap Kondisi Fisiologis Sapi Perah Peranakan Friesien Holland. Buletin Peternakan. $37(3): 189-197$

[3] Hadisutanto, B. 2008. Pengaruh Paritas Induk terhadap Performans Sapi Perah Fries Holland, Bandung.

[4] Kadzere C. T., Murphy M. R., Silanikove N. nd Maltz E. 2002. Heat stress in lactating dairy cows: a review. 77: 59-91 https://doi.org/10.1016/S0301-6226(01)00330-X

[5] McNeilly AS. 2001. Reproduction, fertility, and development. CSIRO Publishing 13:583-590

[6] Krogh, T.H. 2000.Wrong Climate may result in loss of production. SkovA/S Opslag-Artikler.71

[7] Sudono A, Rosdiana F, Setiawan B. 2003. Beternak sapi perah secara intensif. Jakarta (ID): Agromedia Pustaka.

[8] Djaja, W., R.H. Matondang dan Haryono. 2009. Aspek Manajemen Usaha Sapi Perah di Indonesia. Pusat Penelitian dan Pengembangan Peternakan, Badan Penelitian dan Pengembangan Pertanian, Departemen Pertanian. Bogor.

[9] Mukthar, A. 2006. Ilmu Produksi Ternak Perah. Surakarta: LPP dan UNS Prees

[10] Rumetor, S.D. 2003. Stres panas pada sapi perah laktasi. Makalah Falsafah Sains. Program Pascasarjana Institut Pertanian Bogor, Bogor. 